\title{
Obrazowo mówiac. O grach wizualno-werbalnych na okładkach tygodników publicystycznych
}

\author{
Bartlomiej Maliszewski \\ Uniwersytet Marii Curie-Skłodowskiej w Lublinie \\ bmalisz@wp.pl
}

\section{Streszczenie}

Artykut jest poświęcony komunikatom wizualno-werbalnym na okładkach czasopism publicystycznych. Bogaty $w$ znaczenia komunikat, który taczy elementy ikoniczne $i$ stowne, pozwala analizować relacje pomiędzy obydwoma komponentami, a także prześledzić wielopoziomowy charakter odczytywanych treści. W artykule przedstawiono przyktady ikonizacji przekazów werbalnych i ukazano wpływ obrazu na sposób odczytywania słów, a także wpływ języka na sposób interpretowania znaków ikonicznych.

Słowa kluczowe: okładka, semiotyka, multimodalność, obraz, polisemia, metafora

Abstract

Pictorially speaking: On visual and verbal play on the covers of Polish weeklies

The article deals with visual and verbal messages placed on the covers of weekly magazines. Rich in meanings, the message which combines the iconic and verbal elements makes it possible to analyse the relation between those two components as well as to examine multiple levels of the contents involved. The article presents examples of the iconicity of verbal messages, shows the influence of image on the way words are read, as well as the impact of language on the manner iconic signs are interpreted.

Keywords: cover, semiotics, multimodality, image, polysemy, metaphor

\section{Wstęp}

Etymologia terminu okładka wskazuje na obiekt, którego funkcja polega na okrywaniu innej rzeczy ${ }^{1}$. Ów techniczny aspekt okładki schodzi jednak na dalszy plan wraz z uwzględnianiem 
jej funkcji komunikacyjnych. Odwołując się do wyróżnionych przez Stanisława Gajdę (1987: 83) trzech funkcji tytułów: nominatywnej (tytuł nazywa tekst i służy jego identyfikacji), deskryptywnej (tytuł przekazuje informacje o tekście) i pragmatycznej (tytuł oddziałuje na odbiorcę), można stwierdzić, że również okładka czasopisma pełni funkcję identyfikującą, przedstawieniową oraz pragmatyczną. Po pierwsze, stanowi ona znak rozpoznawczy gazety oraz jej kolejnych wydań. Po drugie, jest nośnikiem multimodalnego komunikatu, którym nadawca informuje o treści głównego artykułu, upowszechniając przy tym pewien ogląd rzeczywistości. Po trzecie, jest środkiem zabiegania o uwagę odbiorców, kształtowania postaw i zachęcania do lektury oferowanego produktu.

Aby pozyskać uwagę czytelnika, nadawca przedstawia na okładce temat, który wzbudza szerokie zainteresowanie społeczne ${ }^{2}$, dobiera odpowiednie środki przekazu oraz starannie opracowuje ich kompozycję. Szczególnie ważną rolę odgrywają przy tym znaki ikoniczne, które - jak stwierdza Mieczysław Wallis - działają „na ogół silniej na naszą wyobraźnię i uczuciowość niż znaki umowne reprezentujące podobne przedmioty." (Wallis 1983: 48-49). Nie oznacza to jednak, że słowo drukowane jest już tylko niezbyt znaczącym dodatkiem do obrazu. Komponenty werbalne wyróżniają się swoją wielkością, stanowią przedmiot licznych gier językowych ${ }^{3}$ i ułatwiają interpretację elementów wizualnych ${ }^{4}$, które z kolei dopełniają (bądź modyfikują) przekaz językowy. Tym samym możemy mówić o grach czy figurach wizualno-werbalnych, które Gui Bonsiepe definiuje jako ,ppołączenie znaków dwojakiego typu, których skuteczność w komunikacji zależy od napięcia między ich cechami semantycznymi. Łączny efekt tych znaków polega nie na ich prostym zsumowaniu, ale raczej na ich wzajemnych relacjach.” (Bonsiepe [1985/1972]: 308).

Bogaty w znaczenia komunikat, który łączy elementy wizualne i werbalne, pozwala analizować relację pomiędzy obydwoma komponentami, a także prześledzić wielopoziomowy charakter odczytywanych treści. W poniższym artykule wyróżniamy gry wizualno-werbalne, których zilustrowaniu służą okładki tygodników publicystycznych: Newsweek, Polityka, Wprost z lat 2005-20155. W pierwszej części artykułu przedmiotem analizy jest graficzna forma komponentów słownych, w części drugiej omówieniu podlega wpływ kontekstu wizualnego na sposób odczytywania komunikatów werbalnych oraz wpływ języka na sposób ilustrowania tematu i interpretację obrazu, a w części trzeciej obiektem uwagi są przejawy słownych oraz wizualnych nawiązań do innych utworów.

\section{Obrazowość wyrazów}


Zabiegi graficzne, których przedmiotem są wyeksponowane sformułowania, dotyczą dwóch zjawisk - wyróżniania znaczących elementów przekazu oraz ikonizacji znaków pisarskich. Wyodrębnieniu podlegają m.in. litery reinterpretowanych skrótowców, cząstki wyrazów i wyrażeń przyimkowych, a także leksemy, których odmienna postać graficzna nakazuje czytać tekst na dwa sposoby (z pominięciem bądź uwzględnieniem inaczej zapisanej części tytułu).
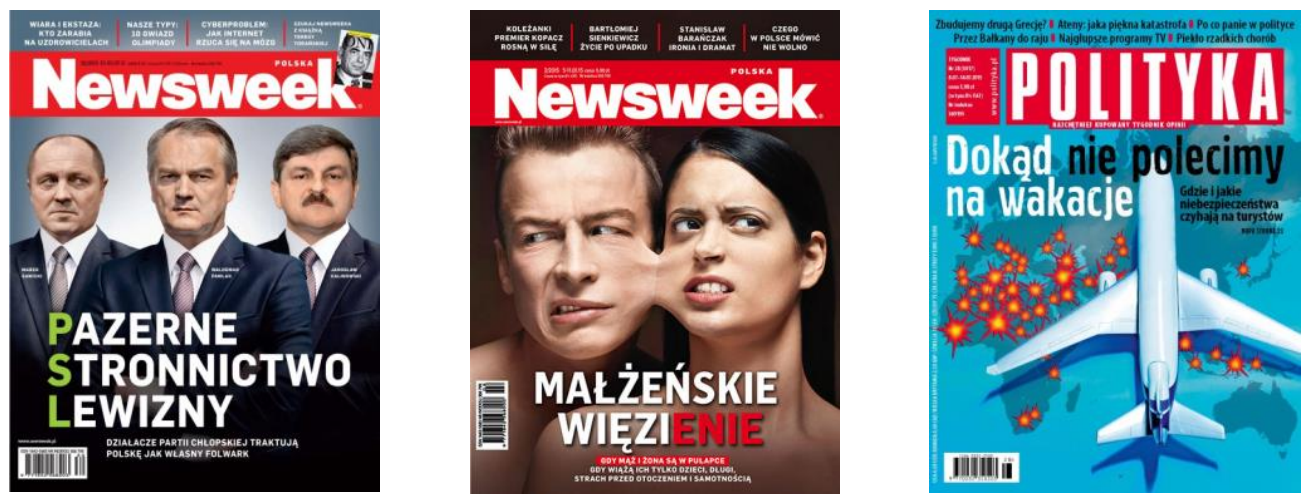

Ryc. 1. Przykłady wyróżniania znaczących elementów przekazu

Ikonizacja komunikatów językowych polega zaś na doborze takiej formy graficznej, której konotacja współgra ze znaczeniem wyeksponowanych leksemów. Takie zabiegi często pojawiają się na plakatach (Wysłouch 1994: 97), w reklamach (Bralczyk 2004: 57), w tytułach w prasie tabloidowej (Wolańska 2007: 323) i na okładkach czasopism (Pacuła 2012), co sprawia, że w rozmaitych przekazach wizualnych odnajdujemy przejawy podobnych sposobów ikonizacji:
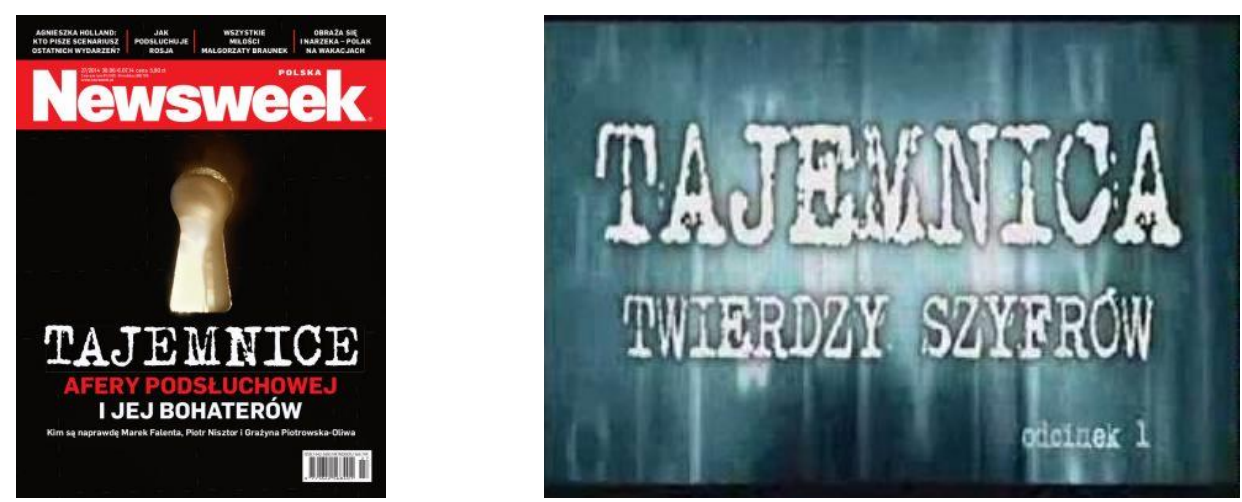

Ryc. 2. Przykłady podobnej ikonizacji komponentów werbalnych w różnych gatunkach przekazu wizualnego (na okładce czasopisma i czołówce serialu)

Słowo tajemnica sprzyja zaintrygowaniu odbiorcy i w obu wypadkach stanowi inicjalny człon tytułu, podlegając graficznemu wyeksponowaniu poprzez użycie większej czcionki. Uwagę wzbudza też kolor oraz krój pisma. Jasna barwa czcionki, która wyróżnia się na 
ciemnym tle, wnosi tu konotację ujawniania pewnych faktów (wydobywania czegoś na światło dzienne), a nieco ,przybrudzone” kontury znaków literowych przywodzą na myśl dokumenty pisane na maszynie i pozwalają sądzić, że wydarzenia, o których jest mowa, są rekonstruowane na podstawie zapisu pewnych (tajnych) informacji.

Wśród licznych okładek łatwo odnaleźć komunikaty językowe, których forma graficzna koresponduje ze znaczeniem wyeksponowanych słów:
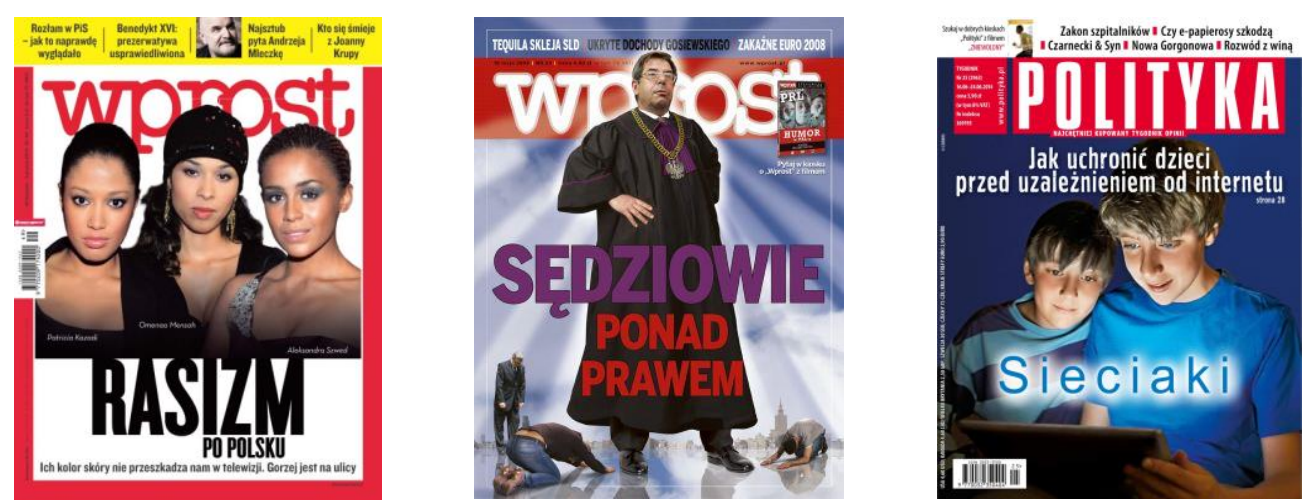

Ryc. 3. Przykłady ikonizacji komponentów werbalnych

Nawet czarny kolor czcionki - pod wpływem kontekstu - nabiera znaczącego charakteru, czego przykładem jest pierwsza okładka z Ryc. 3, która - zapowiadając temat rasizmu opiera się na wyrazistej opozycji czerni i bieli. W tytule Sędziowie ponad prawem człon główny wyróżnia się wielkością oraz odmiennym kolorem, który stanowi nawiązanie do barwy sędziowskiego żabotu. $Z$ treścią oznajmienia koresponduje również układ komponentów werbalnych - wyraz sędziowie znajduje się bowiem ponad pozostałymi członami, których usytuowanie odpowiada komunikowanemu porządkowi rzeczy. $\mathrm{Na}$ następnej okładce uwagę odbiorcy przykuwa zaś kontaminacja Sieciaki, której błękitne i rozświetlone litery odsyłają właśnie do świata multimediów. Można stwierdzić, że sztuka graficznego przedstawienia słów polega na pogodzeniu dwóch dążeń: dbałości o to, by forma znaków pisarskich jak najbardziej wyróżniała się na ikonicznym tle, a zarazem jak najlepiej współgrała z treścią przekazu.

Związki pomiędzy graficzną formą słów, ich znaczeniem oraz prezentowanym obrazem sięgają jeszcze głębiej - w wyeksponowanych leksemach litery bywają zastępowane obrazami (o metonimicznym związku z podejmowanym tematem i o podobnym kształcie, co zastępowany znak literowy ${ }^{6}$ ), a znaki graficzne stają się integralnym komponentem ilustracji. 

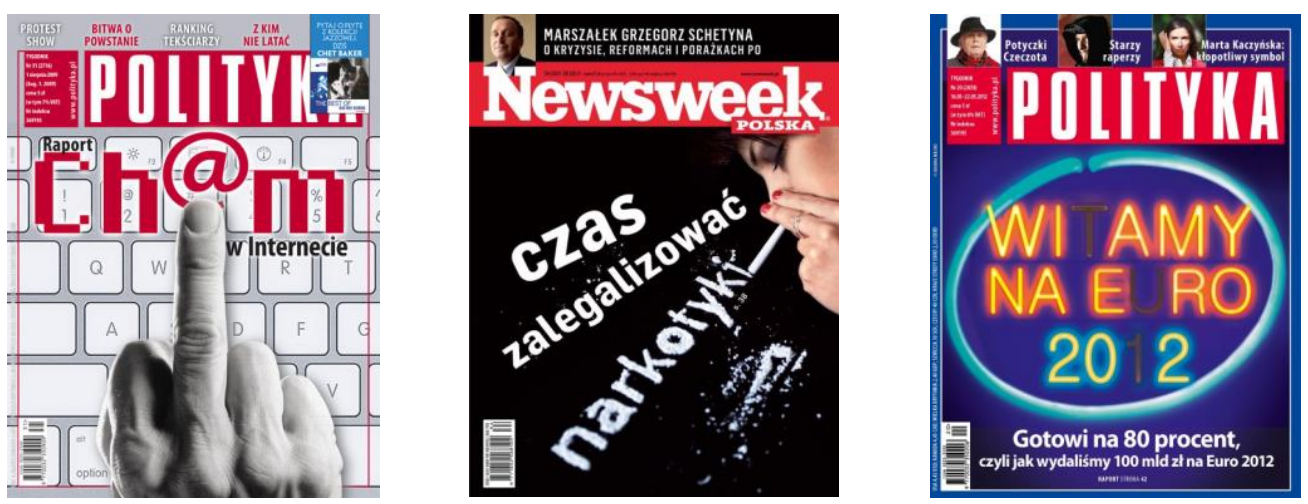

Ryc. 4. Przykłady wykorzystywania znaków pisarskich jako składnika obrazu

Znak @ jest zarówno składnikiem słowa, jak i częścią obrazu - umieszczony nad obelżywym gestem stanowi bowiem jego przedłużenie, informując o tym, że ów obraźliwy emblemat jest posyłany $\mathrm{w}$ wirtualną przestrzeń. Wyraz narkotyki to zarazem obraz porcji białego proszku, a tekst w postaci neonu, w którym niektóre litery nie są „podświetlone”, funkcjonuje również jako ilustracja. Mówiąc o współdziałaniu komunikatów językowych i ikonicznych, należy mieć na względzie to, że słowa drukowane mogą nie tylko towarzyszyć znakom ikonicznym, ale też obejmować obrazy bądź stanowić ich część.

\section{Słowa w kontekście obrazu - obraz w kontekście słów}

W ilustrowanych zapowiedziach artykułów komponenty werbalne pozwalają odnieść się do tego, co abstrakcyjne i bardziej złożone, podczas gdy przedstawiane obrazy bazują na tym, co konkretne. Np. zdjęcia ciemnoskórych Polek wzbudzają uwagę, informując o tym, kto jest bohaterem artykułu, ale to wyrażenie Rasizm po polsku ujawnia sedno podejmowanego zagadnienia, nakazując dostrzec w przedstawianych postaciach ofiary dyskryminacji.

Niemniej - jak stwierdza Walery Pisarek - „Czasem nagłówek nie dość precyzyjnie wskazuje temat wypowiedzi; pomaga mu w tym jej początek" (Pisarek 2002: 166). Także i obraz, który stanowi tło komunikatów językowych, dopełnia ich treść, choć z uwagi na prymarny odbiór znaków ikonicznych trudno tu mówić o analogicznej sytuacji. Przykuwający uwagę obraz sprawia bowiem, że już wcześniej uzyskujemy informację o tym, kogo lub czego dotyczy zapowiadany na okładce artykuł ${ }^{7}$. Np. wizerunek mężczyzny w gronostajowym kołnierzu i w czapce uszance zamiast biretu od razu pozwala zrozumieć, że tytuł Wyższa fikcja (W. 40/2008) odnosi się do negatywnie ocenianych szkół wyższych, choć samo wyrażenie, pozbawione wizualnego kontekstu, nie byłoby łatwe do interpretacji. 
Wpływ obrazu na sposób odbioru tytułu uwidacznia się również przy niespójnej konotacji obu komponentów - rozbieżności pomiędzy deklarowanymi wartościami a przedstawianą istotą rzeczy ${ }^{8}$. Ów dysonans świadczy zarazem o istotniejszym znaczeniu komponentu wizualnego, który nakazuje reinterpretować treść odczytywanych sformułowań.
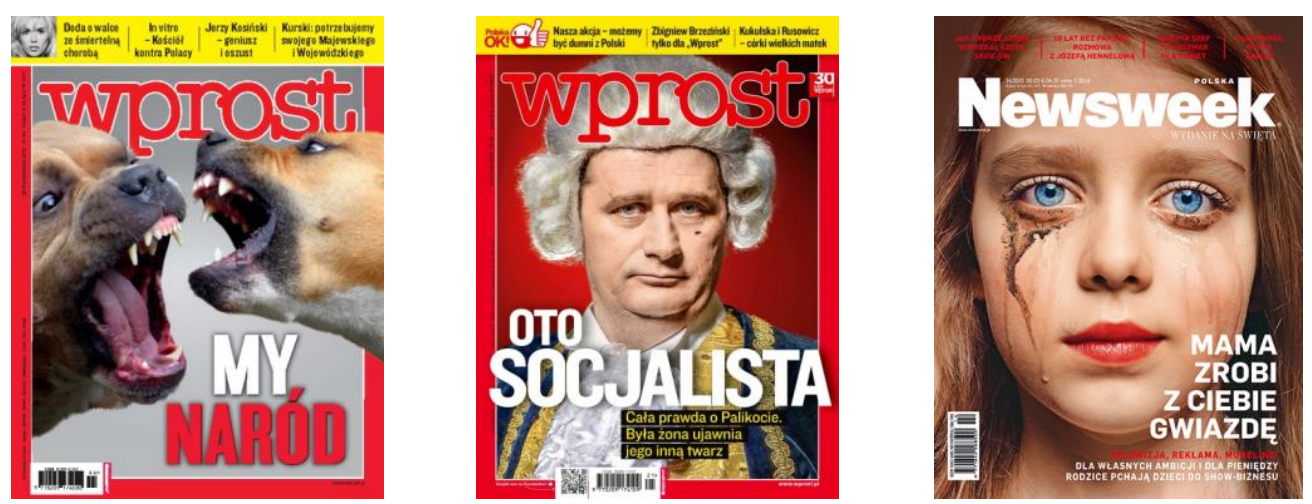

Ryc. 5. Przykłady aksjologicznego kontrastu pomiędzy komponentem wizualnym i werbalnym

Obraz walczących ze sobą psów kontrastuje z podniosłą treścią leksemów napisanych białoczerwoną czcionką (i przywodzących na myśl przemówienie Lecha Wałęsy przed kongresem USA oraz triumf Solidarności). Komunikat językowy zdradza temat artykułu, czyniąc z obrazu nośnik metafory ${ }^{9}$, a kontekst wizualny nakazuje zweryfikować pozytywną konotację słowa naród, zapowiadając gorzką diagnozę panujących relacji społecznych. Wizerunek polityka-arystokraty opatrzony podpisem Oto socjalista nie tylko ujawnia bohatera artykułu, ale i ukazuje nieadekwatość stosowanego sformułowania. Zdjęcie dziewczynki z rozmazanym od płaczu makijażem, wprowadzając w temat artykułu, także kształtuje sposób odczytywania komponentów werbalnych. Zapewnienia: Mama zrobi z ciebie gwiazdę nie możemy traktować jako obietnicy rodem z baśni, gdzie dobra wróżka spełnia marzenia głównej bohaterki. Ukazana postać okazuje się bowiem ofiarą najbliższej jej osoby, która realizując swoje aspiracje - nie liczy się z dobrem dziecka. Słowo i obraz współtworzą tu pewien kontrast aksjologiczny, którego dostrzeżenie wywiera istotny wpływ na sposób interpretowania wypowiedzi językowych (jako przejawu ironii, obnażanej gry pozorów, krytykowanej postawy innych osób).

Odczytywanie komponentów werbalnych poprzez pryzmat znaków ikonicznych łatwo też zaobserwować przy wykorzystywaniu wieloznaczności leksykalnej. Obraz wstrzymuje automatyczny odbiór poszczególnych słów i frazeologizmów, nakazując uwzględnić ich kolejną, mniej oczywistą, treść. 

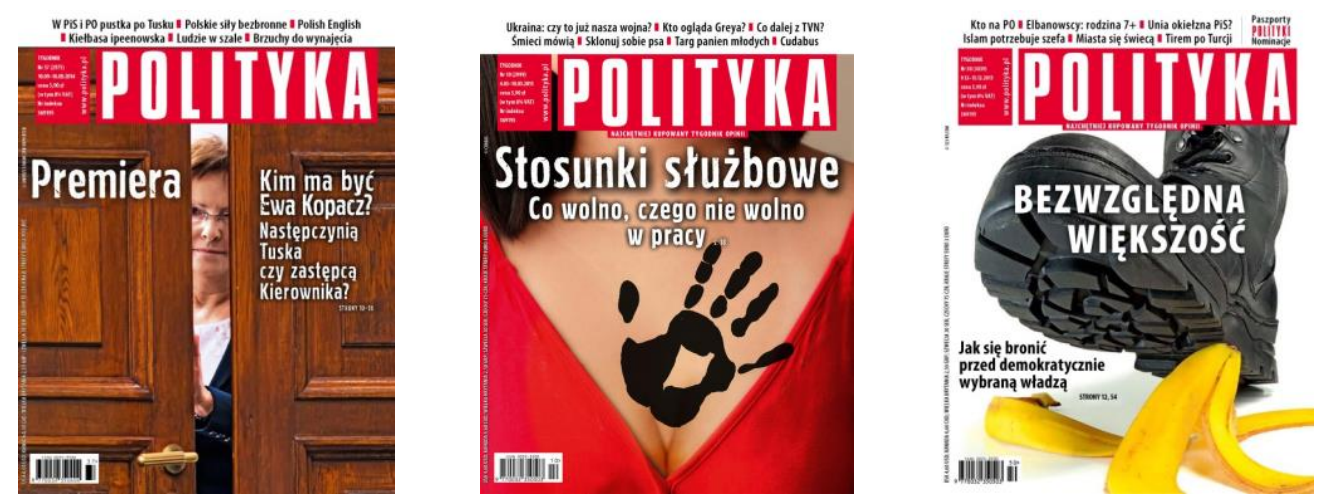

Ryc. 6. Przykłady aktualizowania wieloznaczności leksykalnej poprzez obraz

Wyróżnione graficznie słowa $\mathrm{w}$ połączeniu $\mathrm{z}$ obrazem wzbudzają uwagę poprzez swoją dwuznaczność. Premiera to nie tylko 'pierwsze przedstawienie' i wykładnik metafory teatru (czy metonimia początku), ale również widoczna na zdjęciu pani premier, która w tej nowej roli wchodzi na scenę polityczną. Zestawienie stosunki służbowe na tle zdjęcia dekoltu oraz znaku niewidzialnej ręki nabiera kolejnego znaczenia, odnosząc się do stosunków fizycznych i problemu molestowania $\mathrm{w}$ pracy. Z kolei zestawienie bezwzględna większość, umiejscowione pod zdjęciem żołnierskiego buta, oznacza już nie tylko 'więcej niż połowę głosów', ale staje się też określeniem zbiorowości, która rządzi w sposób bezwzględny. Obraz, przykuwając uwagę odbiorcy, ujawnia zarazem niejednoznaczność użytych słów i modyfikuje sposób ich odczytywania.

Częstym źródłem polisemii jest metafora językowa. W wypadku, gdy zamieszczony na okładce tytuł wykorzystuje utartą przenośnię, ilustracja właśnie do niej się odnosi, co prowadzi do ożywienia werbalnej metafory i kreowania mniej lub bardziej oryginalnych $\operatorname{scen}^{10}$ :
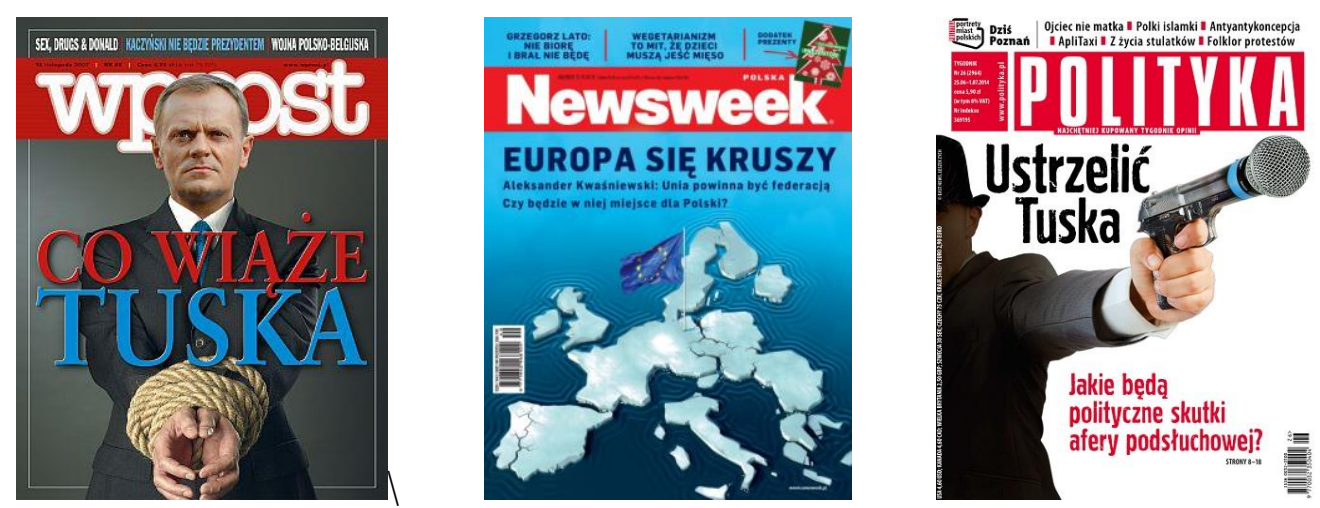

Ryc. 7. Przykłady ożywiania przenośni językowych poprzez metaforę wizualną 
Fotomontaż na pierwszej okładce z Ryc. 7 odwołuje się do utartej przenośni, przedstawiając bohatera artykułu, który śmiało patrzy przed siebie, choć okazuje się całkowicie bezsilny, mając dłonie skrępowane mocnym sznurem. Można więc sądzić, że w zapowiadanym tekście nadawca będzie omawiał polityczne plany przedstawianej postaci, krytycznie oceniając szansę ich realizacji. Na drugiej okładce wykorzystaniu podlega przenośne użycie czasownika kruszyć się, który reifikuje Europę jako łamliwy przedmiot. Obraz ukonkretnia tę metaforę i uściśla treść zdania - jak łatwo zauważyć, mapa przedstawia jedynie kraje Unii Europejskiej, czego oznaką jest też flaga, której maszt wskazuje na Berlin jako najważniejszy ośrodek polityczny. Przedstawienie mapy Unii jako tafli lodu ukierunkowuje sposób rozumienia tytułu i ożywia utartą przenośnię. Na trzeciej okładce uwagę wzbudza zaś obraz zamachowca, który nie tyle patrzy, co nasłuchuje, trzymając w wyciągniętej dłoni pistoletmikrofon. Komunikat językowy dopowiada, kto jest celem przedstawianego ataku, a z kolei ilustracja ukonkretnia treść czasownika i uściśla temat wypowiedzi (obraz pistoletumikrofonu odsyła bowiem do wykorzystywanej w politycznych rozgrywkach afery podsłuchowej).

Sposób graficznego ujęcia tematu zostaje więc utorowany poprzez użyty w tytule frazeologizm, a z kolei obraz aktualizuje warstwę jego znaczeń dosłownych. Choć przy odczytywaniu utartych przenośni przestajemy zauważać współistnienie dwóch składników metafory (tematu oraz nośnika), to jednak obecność obu elementów łatwo wyeksponować, co w komunikatach multimodalnych jest osiągane właśnie poprzez elementy ikoniczne.

Niemniej metafora wizualna nie zawsze stanowi odniesienie do użytej przenośni językowej. Bywa, że komponenty werbalne jedynie dookreślają temat metafory, której wykładnikiem jest sam obraz:
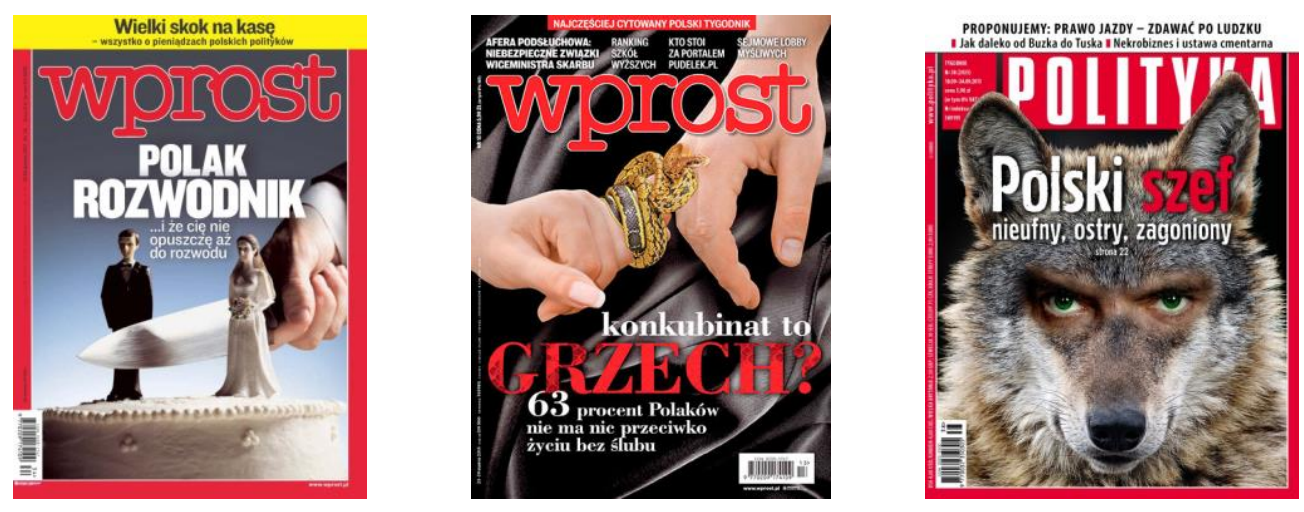

Ryc. 8. Przykłady wizualnych przenośni, których temat dopełniają konstrukcje językowe 
Ilustracja przedstawia dość nietypową kombinację znaków ikonicznych: figurki, umiejscowione po obu stronach weselnego tortu, zostają przedzielone ostrzem noża; dwie dłonie (kobiecą i męską) łączy złocisty wąż, który ,zastępuje” wkładane na palec obrączki; wilk spogląda na nas ludzkimi oczami. Komponent werbalny już wprost określa temat artykułu, uzasadniając posłużenie się taką właśnie ilustracją i wspomagając odbiór jego symbolicznych znaczeń.

Zgodnie z teorią stopów pojęciowych (Fauconnier 1997) w strukturze metafory możemy wyróżnić co najmniej cztery komponenty. Dwie przestrzenie wyjściowe podlegają integracji, współtworząc przestrzeń generyczną (obejmującą to, co wspólne obu komponentom) oraz kreując przestrzeń amalgamatu, której przejawem na okładkach czy plakatach są zarówno metafory językowe, jak i obrazowe. Takim wizualnym wykładnikiem integracji dwóch przestrzeni jest właśnie nietypowa kompozycja znaków ikonicznych (np. obraz zdecydowanego i pewnego siebie polityka ze związanymi rękoma czy obraz tortu, w którym oddalone od siebie figurki państwa młodych dzieli ostrze noża), utożsamianie dwóch różnych obiektów czy zastępowanie jednych elementów innymi (np. mikrofon-pistolet, wilk o ludzkich oczach). Bywają jednak sytuacje, kiedy w obrazie nie dochodzi do łatwo zauważalnych modyfikacji i to komponent werbalny współtworzy metaforę wizualną (np. napis My naród towarzyszący obrazowi dwóch walczących ze sobą psów nakazuje uwzględnić przenośne znaczenie ilustracji) ${ }^{11}$. Obraz kształtuje sposób odczytywania leksemów, a z kolei słowa wpływają na odbiór komponentu wizualnego, ujawniając temat wypowiedzi i precyzując sposób jego ujęcia.

\section{Intertekstualność i interikoniczność}

O ile intertekstualność w literaturze dotyczy jej dialogowego charakteru i gatunków takich jak pastisz czy parodia (zob. Głowiński 2000), o tyle w wypadku tytułów prasowych intertekstualność opiera się na powierzchownych nawiązaniach do innych tekstów (zob. Grochala 2002; Wojenka-Karasek 2009; Ostromęcka-Frączak 2013). Liczne tytuły znanych utworów oraz rozpowszechnione cytaty stają się osnową nagłówków, podlegając dosłownemu przytoczeniu czy modyfikacjom ${ }^{12}$. 

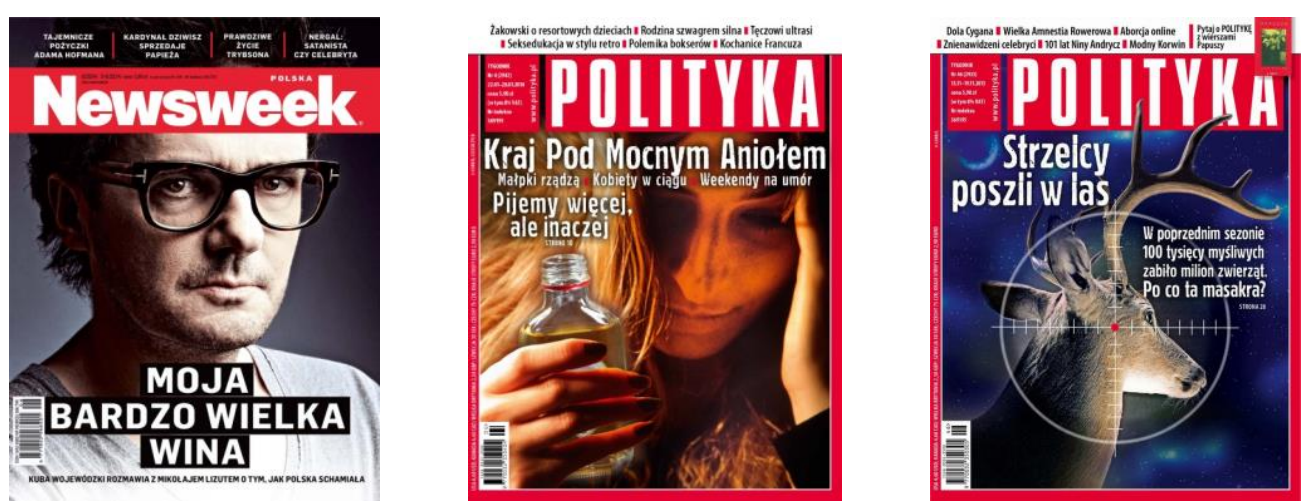

Ryc. 9. Przykłady intertekstualności

Oczywiście, intertekstualne tytuły nie są domeną samych okładek, a od komunikatów multimodalnych możemy oczekiwać, że cytat czy aluzja nie ograniczy się do samych słów, obejmując również obrazy.

Za Aleksandrem Wilkoniem (2002: 58) warto tu więc mówić nie tylko o intertekstualności (zawężanej do zjawisk werbalnych), ale i interikoniczności oraz bardziej złożonych strukturach interznakowych, które odsyłają do innego dzieła poprzez elementy różnych kodów:
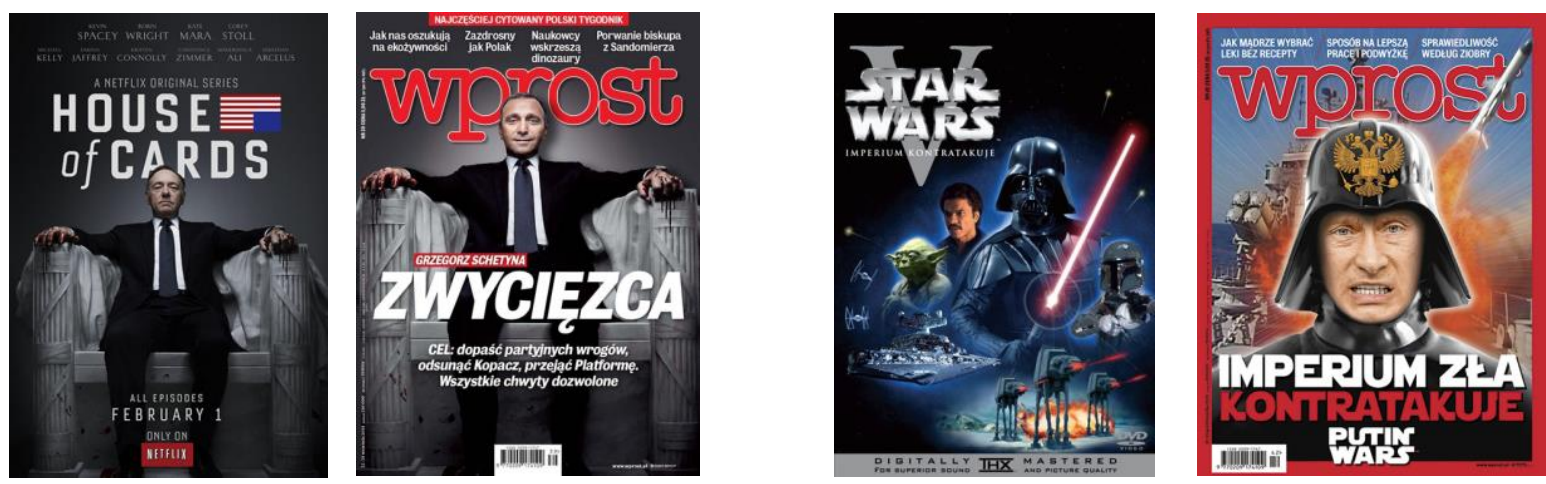

Ryc. 10. Przykład interikoniczności oraz struktury interznakowej

Okładki obu czasopism odsyłają nie tylko do świata rodzimej czy światowej polityki, ale i filmowych bohaterów. Ukazanie jednego z polskich polityków jako bezwzględnego Francisa Underwooda stanowi hiperbolę, która podkreśla ambicje oraz bezkompromisowość bohatera artykułu. Językowe nawiązania do tytułu filmu jednak się nie pojawiają (mamy tu więc do czynienia jedynie z relacją interikoniczną). Inaczej rzecz się ma w wypadku kolejnej okładki, w której wykorzystywanemu obrazowi towarzyszy jeszcze intertekstualny komponent (napisany podobnym krojem czcionki, co tytuł filmowej serii). 
Odwołania do innych dzieł mogą więc się ograniczać do samych słów albo do samych obrazów bądź obejmować oba rodzaje znaków. Oczywiście, nie muszą się one wywodzić z tego samego przekazu - nie ma bowiem przeszkód, by wykorzystując znany plakat czy kadr filmowy opatrzyć go podpisem, który stanowi nawiązanie do jeszcze innego utworu.
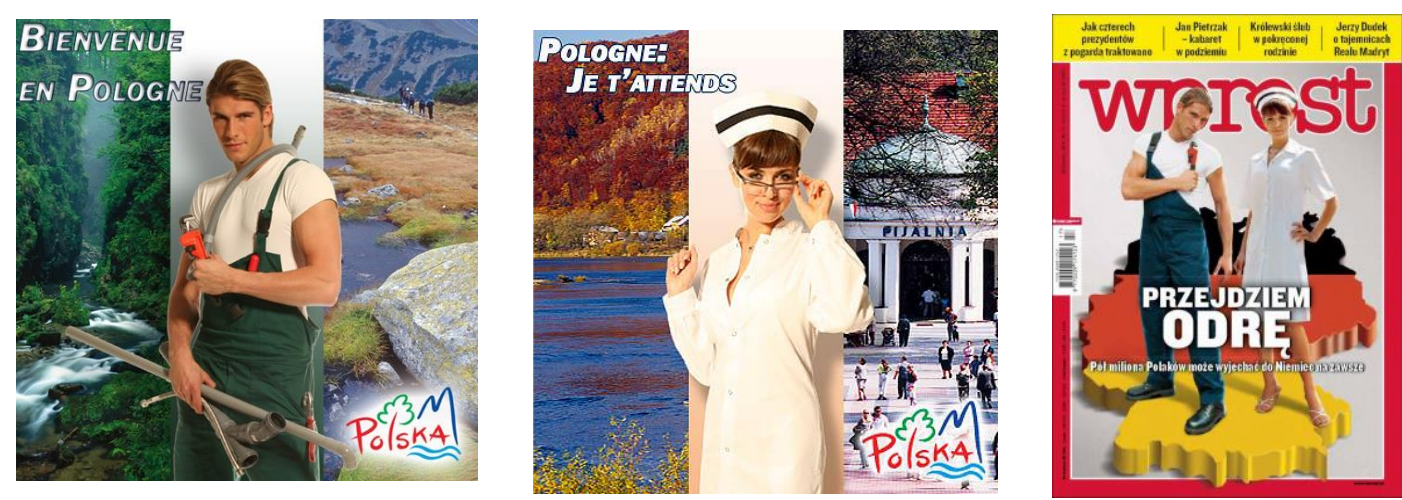

Ryc. 11. Przykład struktury interznakowej, która poprzez warstwę słowną i obrazową odsyła do różnych źródeł

Okładka tygodnika przedstawia postacie z kampanii społecznej, która zyskała dużą popularność, spotykając się z przychylną oceną odbiorców. Hasło „polskiego hydraulika” wykorzystywane we Francji przy wyrażaniu sprzeciwu i obaw wobec napływu taniej siły roboczej ze Wschodu - zostało przewrotnie wykorzystane do promowania Polski (przystojny hydraulik, pozostając w swoim kraju, zaprasza do niego Francuzów), a kontynuacją tej kampanii stał się jeszcze plakat, którego bohaterką jest pielęgniarka zapraszająca do polskich uzdrowisk. Na okładce Wprost obie postaci są w Niemczech, co zostaje wyrażone poprzez symbol mapy-flagi, która widnieje pod stopami dwojga bohaterów. Tytuł Przejdziem Odrę dopełnia ów przekaz, stanowiąc zarazem nawiązanie do kolejnego utworu. Łączenie przeróżnych znaków i posługiwanie się tym, co znane, w zmienionej wersji i w nowym kontekście sprzyja aktywizowaniu uwagi odbiorcy a także zapamiętywaniu treści komunikatu.

\section{Wnioski}

Dominacja obrazu nad tekstem jest trudna do podważenia. Jeśli zapytamy, co jest na okładce, odbiorca zapewne opisze nam obraz, a dopiero w dalszej kolejności przytoczy treść komponentów werbalnych. Niemniej trudno uznać, że słowa pełnią nieistotną funkcję. Leksemy - wyróżniając się formą graficzną - również przykuwają uwagę odbiorcy, a oba 
komponenty współtworzą przekaz, angażując uwagę odbiorcy poprzez wzajemne relacje oraz odniesienia do innych tekstów.

$\mathrm{Z}$ jednej strony to obraz wpływa na sposób odczytywania słów. Element wizualny precyzuje treść tytułu, co sprzyja posługiwaniu się elipsą czy dość ogólnikowymi określeniami. Może też osłabiać dosłowność użytych sformułowań (w wypadku dostrzeganego kontrastu pomiędzy tym, co głosi tekst, a tym, co przedstawia ilustracja). Ponadto pozwala aktualizować różne znaczenia rzeczowników, czasowników, przymiotników, przysłówków, wyrażeń przyimkowych oraz uwydatniać ich metaforyczny charakter. Z drugiej strony to język poprzez bogactwo utartych przenośni ukierunkowuje sposób zilustrowania tematu, a odczytywane komponenty werbalne wpływają na interpretację obrazu. Zarówno znaki słowne, jak i ikoniczne mogą przy tym stanowić nawiązania do utworów, których znajomość przynależy do kompetencji kulturowej użytkowników języka.

\section{Przypisy}

${ }^{1}$ Podobnie rzecz się ma i w obcojęzycznych odpowiednikach tego terminu, np. ros. обложка, czes. obálka, niem. buchdeckel, ang. cover.

${ }^{2}$ Walery Pisarek przywołuje spostrzeżenia K. E. Andersena, który stwierdza, że zainteresowaniem większości odbiorców cieszy się to, co się wiąże z codziennym życiem, jest konkretne i bliskie, konfliktowe, nowe, niezwykłe, nieoczekiwane, wesołe (Pisarek 2002: 170).

${ }^{3}$ Językową analizę tekstów zamieszczanych na okładkach tygodników przeprowadza Alina NaruszewiczDuchlińska (2013).

${ }^{4}$ Jak pisze Roland Barthes: „Tekst prowadzi czytelnika wśród signifiés obrazu, każe mu unikać jednych, a przyswajać inne." (Barthes [1985/1982]: 294).

${ }^{5}$ Numery czasopism, z których pochodzą przedstawiane okładki, są przedstawiane na końcu artykułu.

${ }^{6}$ Takie zabiegi bywają stosowane na okładkach dodatku Newsweek Historia. W sformułowaniu Złoty pociag miejsce znaku $i$ zajmuje ilustracja sztabki złota (10/2015), a w wyrażeniu Święte wojny Moskwy (3/2015) literę $t$ tworzy dolna część krzyża prawosławnego.

${ }^{7}$ Zob. uwagi Marka Kochana (Kochan 2003: 83) na temat percepcji reklamy prasowej.

${ }^{8}$ Samo zestawianie elementów o odmiennych konotacjach stanowi dość częstą osnowę wyeksponowanych komunikatów językowych oraz towarzyszących im obrazów (zob. Piekot 2006: 128-130). Wynika to z dwóch głównych przyczyn. Po pierwsze, uwagę mediów wzbudzają przede wszystkim zdarzenia negatywne i nietypowe (pojawia się tu zatem kontrast pomiędzy opisywanym a należytym stanem rzeczy). Po drugie, łączenie komponentów o odmienych konotacjach sprzyja aktywizowaniu uwagi odbiorcy. Wykładnikami takich kontrastowych zestawień są figury słowne oraz kreowane obrazy (np. wyrażenie matżeńskie więzi staje się członem odmiennie nacechowanej metafory matżeńskiego więzienia, a przedstawiani kochankowie nie są wpatrzeni w siebie, lecz próbują się od siebie uwolnić, mając zrośnięte policzki).

${ }^{9}$ Jak spostrzega Seweryna Wysłouch, jednym ze sposobów przekształcenia znaku ikonicznego w symbol jest dodanie komentarza językowego, „który uchyla referencję i uruchamia konotacje, skutkiem czego znak traci charakter jednostkowy i staje się wieloznaczny, kieruje uwagę nie na przedmiot, ale na zjawisko ogólne, często abstrakcyjne." (Wysłouch 1994: 85).

10 Osnową takich zabiegów są zwykle przenośnie czasownikowe, gdyż - jak zaznacza Aleksander Kiklewicz - projekcje metaforyczne dotyczą zwłaszcza domen rozpatrywanych w zakresie oddziaływania predykatów wyższego rzędu takich jak np. rozpoczęcie, osiąganie czy uniemożliwianie (Kiklewicz 2012: 200201).

${ }^{11}$ Zob. uwagi Wysłouch na temat mechanizmów przemiany znaku ikonicznego w symbol (Wysłouch, 1994: 80-90).

${ }^{12}$ Podobnie jak przy przekształcaniu frazeologizmów mamy tu do czynienia z modyfikacjami fleksyjnymi, syntaktycznymi, dodaniem, ujęciem albo wymianą członu (zob. Pajdzińska 1993). 


\section{Bibliografia}

Barthes, Roland (1985/1982) „Retoryka obrazu”. (tłum.) Zbigniew Kruszyński. [W:] Pamiętnik Literacki z. 3; 289-302. [Przekład według: L'Obvie et l'obtus. Paris: Éditions du Seuil; 25-42].

Bonsiepe, Gui (1985/1972) „Retoryka wizualno-werbalna”. (tłum.) Maria Bożenna Fedewicz. [W:] Pamiętnik Literacki z. 3; 303-309. [Przekład według: „Visual-Verbal Rhetoric”.

[W:] Warren A. Shibles (red.) Essays on Metaphor. Wisconsin: Whitewater; 155$161]$.

Bralczyk, Jerzy (2004) Język na sprzedaż. Gdańsk: Gdańskie Wydawnictwo Psychologiczne. Fauconnier, Gilles (1997) Mappings in Thought and Language. San Diego: University of California.

Gajda, Stanisław (1987) „Społeczna determinacja nazw własnych tekstów (tytułów)”. [W:] Socjolingwistyka, t. 6; 82-95.

Głowiński, Michał (2000) Intertekstualność, groteska, parabola. Kraków: UNIVERSITAS. Grochala, Beata (2002) „Intertekstualność w nagłówkach 'Gazety Wyborczej””. [W:] Kazimierz Michalewski (red.) Tekst w mediach. Łódź: Wydawnictwo Uniwersytetu Łódzkiego; 222-229.

Kiklewicz, Aleksander (2012) Znaczenie w języku - znaczenie w umyśle. Olsztyn: Wydawnictwo Uniwersytetu Warmińsko-Mazurskiego w Olsztynie.

Kochan, Marek (2003) „Tekst i obraz w reklamie prasowej”. [W:] Katarzyna MosiołekKłosińska, Tadeusz Zgółka (red.) Język perswazji publicznej. Poznań: Wydawnictwo Poznańskie; 83-90.

Naruszewicz-Duchlińska, Alina (2013) „Analiza językowa okładek tygodników opinii na przykładzie 'Polityki', 'Przekroju' i 'Wprost'”. [W:] Prace Językoznawcze 15/1; 5772.

Ostromęcka-Frączak, Bożena (2013) „Nagłówki prasowe”. [W:] Agata Małyska, Anna Dunin-Dudkowska (red.) 70 lat współczesnej polszczyzny. Zjawiska, procesy, tendencje. Lublin: Wydawnictwo UMCS, 463-470.

Pacuła, Jarosław (2012) „Grafizacja i wizualizacja słowa w zapowiedziach medialnych”. [W:] Media i Społeczeństwo $\mathrm{nr} 2 ;$ 74-93.

Pajdzińska, Anna (1993) Frazeologizmy jako tworzywo wspótczesnej poezji. Lublin: Wydawnictwo UMCS. 
Piekot, Tomasz (2006) Dyskurs polskich wiadomości prasowych. Kraków: UNIVERSITAS.

Pisarek, Walery (2002) Nowa retoryka dziennikarska. Kraków: UNIVERSITAS.

Wallis, Mieczysław (1983) Sztuki i znaki. Pisma semiotyczne. Warszawa: Państwowy Instytut Wydawniczy.

Wilkoń, Aleksander (2002) Spójność i struktura tekstu: wstęp do lingwistyki tekstu. Kraków: UNIVERSITAS.

Wojenka-Karasek, Magdalena (2009) „Intertekstualność w nagłówkach tygodnika 'Polityka'”. [W:] Jan Sosnowski (red.) Problemy semantyki i stylistyki tekstu. Łódź: Wydawnictwo Uniwersytetu Łódzkiego; 353-365.

Wojtak, Maria (2004) Gatunki prasowe. Lublin: Wydawnictwo UMCS.

Wolańska, Ewa (2007) „Współdziałanie słowa i obrazu w prasie tabloidowej. Ujęcie semiotyczne". [W:] Grzegorz Szpila (red.) Język polski XXI wieku: analizy, oceny, perspektywy. Kraków: Krakowskie Towarzystwo „Tertium”; 311-325.

Wysłouch, Seweryna (1994) Literatura a sztuki wizualne. Warszawa: Wydawnictwo Naukowe PWN.

\section{Źródła ilustracji}

Okładki tygodnika Newsweek nr 34/2011, nr 49/2011, nr 30/2012, nr 6/2014, nr 27/2014, nr $14 / 2015, \mathrm{nr} 2 / 2015$.

Okładki tygodnika Polityka nr 31/2009, nr 20/2012, nr 38/2013, nr 46/2013, nr 4/2014, nr 25/2014, nr 26/2014, nr 37/2014, nr 10/2015, nr 28/2015, nr 50/2015.

Okładki tygodnika Wprost nr 13/2005, nr 46/2007, nr 20/2008, nr 44/2010, nr 49/2010, nr 17/2011, nr 34/2011, nr 21/2012, nr 39/2014, nr 42/2015.

Plakaty Polskiej Organizacji Turystycznej - „Polski hydraulik”, „Polska pielęgniarka”

Okładki filmów: „House of Cards” (wytwórnia filmowa: Netflix), „Gwiezdne wojny” „Imperium kontratakuje” (wytwórnia filmowa: Lucasfilm)

Kadr z serialu: „Tajemnica twierdzy szyfrów” (emisja: TVP1)

Materiały ikoniczne zostały zaczerpnięte za pośrednictwem stron:

www.e-kiosk.pl

www.signs.pl/artykul.php? sid $=2858 \&$ fo $=1$

www.wiadomosci.wp.pl/polska-pielegniarka-podbija-swiat-6038691151860353g

www.icefilms.info/tv/series/5/4043 
www.filmweb.pl/Imperium.Kontratakuje/posters

www.vod.tvp.pl

[ostatni dostęp do wymienionych stron internetowych: 01.12.2017 r.] 